\title{
HUBUNGAN KESULITAN KEUANGAN DENGAN MANAJEMEN LABA PADA PERUSAHAAN YANG TERDAFTAR DI BURSA EFEK INDONESIA TAHUN 2010-2016
}

\author{
Ferix Feldo, \\ Rinaningsih, \\ Retno Yuliati \\ Sekolah Bisnis dan Ekonomi, Universitas Prasetiya Mulya \\ retno.yuliati@pmbs.ac.id
}

\begin{abstract}
This research aims to know how the relationship between financial distress as measured by manajemen laba using Discretionary value Accruals (DA). This research use quantitative approach and the population used is the all of company listed in the Indonesian Stock Exchange period 20102016. Research conducted using multiple linear regression. The result of the research indicate (1) there is a negative significant relationship between financial distress in distress 1 category characterized by a negative net income during the current year with earnings management. (2) there is no significant relationship between financial distress in distress 2 category characterized by negative working capital during the current year with manajemen laba, (3) there is on relationship between financial distress in distress 3 category characterized by negative net income and working capital during the current year with manajemen laba.
\end{abstract}

Keywords : Discretionary Accruals, Manajemen laba, Financial Distress

\section{PENDAHULUAN}

Perusahaan adalah sebuah organisasi yang memiliki tujuan untuk mencari keuntungan sebagai tujuan utamanya dan tidak menutup kemungkinan mencapai kemakmuran sebagai tujuan lainnya (Gitosudarmo,2002). Menurut Martono dan Harjito (2010) tujuan perusahaan adalah untuk mencapai laba yang maksimal serta mengandung konsep bahwa perusahaan harus melakukan kegiatan usahanya secara efektif dan efisien. Di samping itu, terdapat tujuan lain perusahaan, yaitu berkelanjutan (going concern), berkembang (growth), serta dapat melaksanakan fungsi-fungsi sosial lainnya di masyarakat. Kesulitan keuangan merupakan salah satu hal yang tidak diinginkan oleh perusahaan, baik itu dari pihak internal maupun eksternal perusahaan. Kesulitan keuangan merupakan suatu kondisi ketika aliran kas operasi sebuah perusahaan tidak cukup untuk membayar kewajiban-kewajiban yang ada sehingga dapat mengganggu kegiatan operasional perusahaan.

Menurut Elmabrok (2012), kesulitan keuangan terjadi ketika jumlah kewajiban melebihi nilai wajar aset atau ketika kewajiban lancar melebihi aktiva lancar. Masalah kesulitan keuangan ini semakin mendapat perhatian sejak pertengahan tahun 1997 ketika terjadinya krisis finansial yang cukup hebat di Indonesia yang ditandai dengan adanya krisis keuangan yang berkelanjutan sehingga menjadi krisis ekonomi yang berkepanjangan. Selain itu pada tahun 2008 krisis keuangan kembali terjadi, krisis yang lebih dikenal sebagai krisis ekonomi global ini mengakibatkan perputaran roda ekonomi Indonesia melambat dan dampak krisis keuangan yang bermula di Amerika Serikat ini telah menjalar ke berbagai negara. Pengalaman buruk ketika krisis ekonomi 1997 dan 2008 membuktikan bahwa unit-unit ekonomi di negara ini sangat sensitif terhadap peristiwa-peristiwa yang berkaitan dengan ekonomi. Dampak krisis ekonomi yang dialami perusahaan secara terus menerus akan dapat menyebabkan perusahaan mengalami kesulitan keuangan. Oleh karena itu, manajemen memiliki peran utama dalam kelangsungan hidup perusahaan. Hal ini tentu saja mendorong manajer untuk mengambil berbagai tindakan sehingga terhindar dari kondisi tersebut. Salah satu cara yang digunakan oleh manajer adalah manajemen laba. Penelitian manajemen laba yang dilakukan oleh 
Ahmed et al. (2008) membuktikan bahwa manajer akan lebih terlibat dalam penurunan pendapatan pada manajemen laba selama periode krisis.

Scott (2015) menyatakan bahwa manajemen laba merupakan pemilihan kebijakan akuntansi yang dilakukan oleh manajer menurut standar akuntansi yang ada dan secara alamiah dapat memaksimalkan utilitas mereka dan atau nilai pasar perusahaan. Menurut teori keagenan, manajemen laba terjadi dikarenakan terdapat perbedaan kepentingan antara manajemen dengan investor dikarenakan setiap pihak memiliki tujuan masing-masing yaitu memaksimalkan keuntungan yang diperolehnya.

Penelitian yang dilakukan oleh Habib,et al. (2012) menyatakan bahwa terdapat hubungan negatif signifikan antara perusahaan yang mengalami kesulitan keuangan dengan manajemen laba. Penelitian tersebut menyimpulkan bahwa ketika perusahaan semakin mengalami kesulitan keuangan, maka akan melakukan manajemen laba dengan cara menurunkan laba usaha mereka. Hasil yang sama juga didapatkan oleh Dechow (1995) yang menggunakan data dari periode selama Global Financial Crisis, yaitu tahun 2008-2010 di Amerika. Hasil penelitiannya menunjukkan bahwa perusahaan yang mengalami kesulitan keuangan maka manajemen laba semakin turun. Vega dan Amanah (2014) juga mendapatkan hasil bahwa terdapat hubungan signifikan tidak searah antara kesulitan keuangan dengan manajemen laba.

Sementara itu, penelitian yang dilakukan oleh Gunawan et al. (2014) mendapatkan hasil yang berbeda. Pada penelitian tersebut dinyatakan bahwa terdapat hubungan positif signifikan antara kesulitan keuangan dengan manajemen laba. Hal tersebut berarti ketika perusahaan mengalami kesulitan keuangan maka akan cenderung melakukan manajemen laba dengan cara menaikkan laba usaha mereka dibandingkan perusahaan yang tidak mengalami kesulitan keuangan. Hal ini didukung dengan penelitian yang dilakukan oleh Rosner (2003) dan Gamayuni (2007) yang meneliti perusahaan yang mengalami kebangkrutan. Hasil dari penelitian tersebut menyatakan bahwa manajer perusahaan yang mengalami kesulitan keuangan, khususnya perusahaan dengan pelanggaran perjanjian utang akan lebih banyak melakukan praktek manajemen laba. Inkonsistensi hasil-hasil penelitian terdahulu menjadi alasan mengapa penelitian ini dilakukan, yakni untuk mengetahui lebih jauh hubungan antara kesulitan keuangan dengan manajemen laba.

\section{KAJIAN TEORI DAN PENGEMBANGAN HIPOTESIS 2.1. Teori Keagenan}

Teori keagenan berkaitan dengan masalah yang terjadi antara prinsipal dan agen (Jensen dan Meckling, 1976). Teori keagenan menyatakan menyatakan bahwa praktik manajemen laba yang dilakukan manajemen suatu badan usaha dipengaruhi oleh adanya konflik kepentingan. Menurut Scott (2015), konflik antara agen dan prinsipal terjadi pada perusahaan yang mempunyai banyak kontrak, misalnya kontrak kerja antara perusahaan dengan para manajernya dan kontrak pinjaman antara perusahaan dengan krediturnya. Kontrak kerja yang dimaksud adalah kontrak kerja antara pemilik modal dengan manajer perusahaan atau antara agen dan prinsipal yang ingin memaksimalkan utility masing masing dengan informasi yang dimiliki.

Dengan demikian terdapat dua kepentingan yang berbeda di dalam perusahaan untuk mencapai atau mempertahankan tingkat kemakmuran yang dikehendaki. Di satu sisi, agen memiliki informasi yang lebih banyak dibanding dengan prinsipal, sehingga menimbulkan asimetri informasi. Asimetri informasi dan perbedaan kepentingan yang terjadi antara prinsipal dan agen mendorong agen untuk menyajikan informasi yang tidak sebenarnya kepada prinsipal, terutama jika informasi berkaitan dengan pengukuran kinerja agen. Adanya asimetri informasi antara manajemen dengan pemilik dapat menjadi peluang bagi manajer untuk melakukan tindakan earnings management yaitu memanipulasi informasi yang akan diterima pemilik mengenai kinerja ekonomi perusahaan.

\subsection{Teori Sinyal}

Menurut Brigham dan Houston (2006), isyarat atau signal adalah suatu tindakan yang diambil perusahaan untuk memberi petunjuk bagi investor tentang bagaimana manajemen memandang prospek perusahaan. Signalling theory secara umum membahas bagaimana seharusnya sinyal-sinyal keberhasilan yang dicapai manajemen juga kegagalan yang dialaminya disampaikan kepada para 
pemilik badan usaha (prinsipal). Signaling theory menjelaskan mengapa perusahaan mempunyai dorongan untuk memberikan informasi laporan keuangan pada pihak eksternal. Dorongan perusahaan untuk memberikan informasi karena terdapat asimetri informasi antara perusahaan dan pihak luar karena perusahaan mengetahui lebih banyak mengenai perusahaan dan prospek yang akan datang dari pada pihak luar. Artinya manajemen memiliki asimetri informasi sehingga manajemen mampu mengendalikan informasi yang ada di dalam suatu badan usaha. Asimetri informasi inilah yang memberikan insentif kepada manajemen untuk melakukan moral hazard dalam bentuk manajemen laba (manajemen laba) dengan tujuan untuk memaksimumkan kemakmurannya.

\subsection{Manajemen laba}

Scott (2015) mendefinisikan manajemen laba sebagai pemilihan kebijakan akuntansi yang diambil oleh manajer sesuai standar akuntansi yang berlaku dan secara tidak langsung dapat memaksimalkan kepentingan mereka atau nilai perusahaan. Menurut Fischer dan Rosenzweig (1995) manajemen laba merupakan tindakan yang dilakukan oleh manajer dengan cara menaikkan ataupun menurunkan laba yang dilaporkan yang tidak mempunyai hubungan dengan kenaikkan atau penurunan labaabilitas perusahaan dalam jangka panjang. Assih dan Gudono (2000) mengatakan bahwa manajemen laba merupakan proses yang dilakukan dengan sengaja dalam batasan General Addopted Accounting Principles untuk mengarah pada tingkatan laba yang dilaporkan. Berdasarkan beberapa definisi tersebut, dapat disimpulkan bahwa manajemen dapat melakukan manajemen laba dalam batasan tertentu dan sesuai ketentuan akuntansi yang berlaku.

\subsection{Kesulitan Keuangan}

Menurut Supardi (2003), kesulitan keuangan merupakan kegagalan perusahaan dalam menjalankan kegiatan operasional perusahaan dalam menghasilkan laba. Riyanto (2001) menyatakan bahwa terdapat dua faktor yang menyebabkan kegagalan suatu perusahan, yaitu internal dan eksternal. Faktor internal sendiri merupakan faktor-faktor yang timbul dari dalam perusahaan baik itu dari segi finansial maupun nonfinansial. Faktor finansial sendiri bisa terjadi karena lebih besarnya hutang jangka pendek perusahaan terhadap current asset perusahaan. Hal tersebut bisa terjadi dikarenakan lambatnya perputaran piutang perusahaan atau banyaknya piutang tak tertagih. Faktor nonfinansial sendiri bisa saja terjadi karena kesalahan dalam penentuan produk yang dihasilkan, struktur organisasi, kesalahan dalam pemilihan manajemen dan kebijakan atau keputusan yang diambil oleh perusahaan. Faktor eksternal merupakan faktor-faktor yang timbul ataupun berasal dari luas perusahaan seperti terdapatnya persaingan yang ketat antar perusahaan, berkurangnya permintaan terhadap produk yang dihasilkan, dan lain-lain.

\subsection{Hubungan Antara Kesulitan Keuangan dengan Manajemen laba}

Kesulitan keuangan merupakan ketidakmampuan perusahaan memenuhi kewajibankewajibannya atau dengan kata lain perusahaan mengalami insolvency. Platt dan Platt (2006) mendefinisikan kesulitan keuangan sebagai suatu kondisi perusahaan yang sedang mengalami penyimpangan dan tekanan yang secara bertahap akan mengarah kepada kebangkrutan. Kebangkrutan sendiri diartikan dengan kegagalan perusahaan membayar kewajiban. Kesulitan keuangan terjadi sebelum perusahaan mengalami kebangkrutan. Dengan adanya kesulitan keuangan, maka diharapkan perusahaan dapat melakukan tindakan-tindakan untuk mengantisipasi kondisi tersebut. Pada umumnya, tindakan yang dapat diambil oleh perusahaan dapat berupa penghentian operasi, pabrik, atau divisi, pengurangan produksi, penundaan proyek tertentu, tidak membayar dividen maupun pengurangan jumlah karyawan (Fachrudin, 2008). Namun perusahaan juga dapat mengantisipasi kondisi kesulitan keuangan dengan melakukan praktek manajemen laba sehingga diharapkan dapat menyelamatkan perusahaan dari kondisi tersebut. Koch (2002) menyatakan bahwa perilaku manajemen laba akan meningkat seiring meningkatnya tingkat kesulitan keuangan perusahaan.

Penelitian yang dilakukan oleh Habib,et al. (2013) menyatakan bahwa terdapat hubungan negatif signifikan antara perusahaan yang mengalami distress dengan manajemen laba. Penelitian tersebut menyimpulkan bahwa ketika perusahaan semakin distress, maka akan lebih sedikit melakukan praktek manajemen laba dibandingkan perusahaan yang sehat. Penelitian ini didukung oleh Dechow 
et al. (1995) yang menggunakan data dari periode selama Global Financial Crisis, yaitu tahun 20082010 di Amerika yang menunjukkan bahwa perusahaan yang semakin distress maka manajemen laba semakin turun. Hasil yang sama juga didapatkan dari penelitian yang dilakukan oleh Vega dan Amanah (2014) yang menyatakan bahwa terdapat hubungan signifikan tidak searah antara kesulitan keuangan dengan manajemen laba. Hal ini berarti perusahaan yang mengalami tingkat kesulitan yang sangat parah akan melakukan manajemen laba dengan cara menurunkan laba usaha mereka.

Penelitian yang dilakukan oleh Gunawan et al. (2014) menyatakan bahwa perusahaan yang mengalami kesulitan keuangan yang ditandai dengan net income dan working capital negatif maka akan cenderung melakukan praktik manajemen laba dibandingkan perusahaan yang tidak mengalami kesulitan keuangan. Hal ini didukung dengan penelitian yang dilakukan oleh Rosner (2003) yang meneliti 293 perusahaan bangkrut. Hasil dari penelitian tersebut menyatakan bahwa manajer perusahaan yang mengalami kesulitan keuangan, khususnya perusahaan dengan pelanggaran perjanjian utang maka akan lebih banyak melakukan praktek manajemen laba. Gamayuni (2007) yang meneliti tentang praktek manajemen laba pada perusahaan yang mengalami kebangkrutan di Indonesia juga menemukan hasil bahwa terdapat praktek manajemen laba yang lebih tinggi secara signifikan pada perusahaan bangkrut dibandingkan dengan perusahaan yang tidak bangkrut selama empat tahun sebelum terjadinya kebangkrutan.

Hal ini berarti manajer perusahaan yang mengalami tingkat kesulitan keuangan yang sangat parah akan cenderung melakukan praktek manajemen laba untuk menyembunyikan kinerja buruknya (Lo, 2012). Tindakan manajemen tersebut dilakukan karena perusahaan telah mengalami kerugian dan jumlah utang lancar melebihi aset lancar yang dimiliki perusahaan selama tahun berjalan, sehingga perusahaan tidak mampu untuk menutupi utang yang besar tersebut (Gunawan,2014). Hal ini berarti apabila working capital juga negatif maka perusahaan tidak bisa mengakui beban-beban tahun depan sebagai beban-beban pada saat ini sebab pengakuan beban yang semakin besar di sisi lain akan menyebabkan nilai aset lancar semakin berkurang.

Dari beberapa penjelasan tersebut, dapat dilihat bahwa masih belum terdapat hasil yang jelas antara kesulitan keuangan dengan manajemen laba. Tetapi menurut peneliti manajer perusahaan yang mengalami kesulitan keuangan akan cenderung menaikkan laba usaha mereka (hubungan positif) dikarenakan manajer perusahaan bangkrut akan berusaha menutupi kondisi tersebut sehingga mereka masih mendapatkan bonus dan posisi mereka tidak terancam. Hal ini sesuai dengan salah satu motivasi manajer melakukan manajemen laba yaitu Bonus Plan Hypotesis. Oleh karena itu maka dirumuskan hipotesis sebagai berikut:

\section{H1 : Terdapat hubungan negatif antara kesulitan keuangan dengan manajemen laba.}

\section{Metode Penelitian}

\subsection{Sampel dan Data}

Sampel yang digunakan dalam penelitian ini adalah perusahaan yang telah go public dan terdaftar di Bursa Efek Indonesia ( kecuali perusahaan keuangan ) pada periode 2010-201

\subsection{Operasionalisasi Variabel}

\subsubsection{Variabel Dependen}

Variabel dependen dalam penelitian ini adalah manajemen laba yang diukur menggunakan proxy discretionary accruals (DA) dengan tiga pengukuran yaitu :

\section{a) The Modified Jones Model (1995)}

$$
\frac{\mathrm{TACCR}}{\mathrm{At}-1}=\alpha 1\left(\frac{1}{\mathrm{At}-1}\right)+\alpha 2\left(\frac{\Delta \mathrm{REVit}-\Delta \mathrm{RECit}}{\mathrm{At}-1}\right)+\alpha 3\left(\frac{\text { PPEit }}{\mathrm{At}-1}\right)+e i t
$$

Keterangan :

TACCR = Total Akrual (Net Interest Before Extra Ordinary Item-Cash Flow from

Operating)

$\triangle \mathrm{REV}_{\mathrm{t}} \quad=$ Pendapatan pada tahun $\mathrm{t}$ dikurangi pendapatan pada tahun $\mathrm{t}-1$

$\triangle \mathrm{REC}_{\mathrm{t}} \quad=$ Selisih piutang bersih pada tahun $\mathrm{t}$ dan piutang bersih pada $\mathrm{t}-1$

PPE = Property, plant, and equipment pada tahun $\mathrm{t}$

$\mathrm{A}_{\mathrm{t}-} \quad=$ Total aset pada $\mathrm{t}-1$

$\alpha_{1}, \alpha_{2}, \alpha_{3}=$ Parameter spesifik perusahaan 
b) Kazsnik Model (1999)

eit $\quad=$ Discretionary Accruals

$$
\frac{\mathrm{TACCR}}{\mathrm{At}-1}=\alpha 1\left(\frac{1}{\mathrm{At}-1}\right)+\alpha 2\left(\frac{\Delta \mathrm{REVit}-\triangle \mathrm{RECit}}{\mathrm{At}-1}\right)+\alpha 3\left(\frac{\mathrm{PPEit}}{\mathrm{At}-1}\right)+\alpha 3\left(\frac{\Delta C F O}{\mathrm{At}-1}\right)+e i t
$$

Keterangan :

TACCR = Total Akrual (Net Interest Before Extra Ordinary Item-Cash Flow from

Operating)

$\triangle \mathrm{REV}_{\mathrm{t}} \quad=$ Pendapatan pada tahun $\mathrm{t}$ dikurangi pendapatan pada tahun $\mathrm{t}-1$

$\triangle \mathrm{REC}_{\mathrm{t}} \quad=$ Selisih piutang bersih pada tahun $\mathrm{t}$ dan piutang bersih pada $\mathrm{t}-1$

$\mathrm{PPE}_{\mathrm{t}} \quad=$ Property, plant, and equipment pada tahun $\mathrm{t}$

$\triangle C F O=$ Selisih arus kas operasi pada tahun $\mathrm{t}$ dikurangi tahun sebelumnya

$\mathrm{A}_{\mathrm{t}-1} \quad=$ Total aset pada $\mathrm{t}-1$

$\alpha_{1}, \alpha_{2}, \alpha_{3} \quad=$ Parameter spesifik perusahaan

eit $\quad=$ Discretionary Accruals

c) Kothari et al. (2005)

$\frac{\text { TACCR }}{\text { At }-1}=\alpha 1\left(\frac{1}{\mathrm{At}-1}\right)+\alpha 2\left(\frac{\Delta \text { REVit }}{\mathrm{At}-1}\right)+\alpha 3\left(\frac{\text { PPEit }}{\mathrm{At}-1}\right)+\alpha 3\left(\frac{\mathrm{ROA}}{\mathrm{At}-1}\right)+$ eit.......... (3)

Keterangan :

TACCR $=$ Total Akrual (Net Interest Before Extra Ordinary Item - Cash Flow from

Operating)

$\triangle \mathrm{REV}_{\mathrm{t}}=$ Pendapatan pada tahun $\mathrm{t}$ dikurangi pendapatan pada $\mathrm{t}-1$

$\mathrm{PPE}_{\mathrm{t}} \quad=$ Property, plant, and equipment pada tahun $\mathrm{t}$

$\mathrm{ROA}=$ Return on asset

$\mathrm{A}_{\mathrm{t}-1} \quad=$ Total aset pada $\mathrm{t}-1$

$\alpha_{1}, \alpha_{2}, \alpha_{3}=$ Parameter spesifik perusahaan

eit $\quad=$ Discretionary Accruals

\subsubsection{Variabel Independen}

Financial Distress. Dalam penelitian ini, kesulitan keuangan dikategorikan berdasarkan adaptasi dari McKeown et al. (1991), Hopwood et al., (1994), dan Mutchler et al. (1997) yaitu berdasarkan kondisi:

- Mengalami net income negatif selama tahun berjalan (Distress 1)

- Modal kerja (working capital) negatif selama tahun berjalan (Distress2)

- Modal kerja dan net income negatif selama tahun berjalan (Distress3)

Perusahaan yang memenuhi salah satu dari ketiga kriteria di atas akan diberi nilai 1 , dan nilai 0 apabila perusahaan tidak memenuhi salah satu dari ketiga kategori di atas.

\subsubsection{Variabel Kontrol}

Size, merupakan ukuran perusahaan yang diukur sebesar nilai $l n$ dari total aset. Semakin besar ukuran perusahaan, biasanya informasi yang tersedia untuk investor dalam pengambilan keputusan sehubungan dengan investasi dalam saham perusahaan tersebut semakin banyak. Albrecth \& Richardson (1990) menemukan bahwa perusahaan yang lebih besar kurang memilki dorongan untuk melakukan perataan laba dibandingkan perusahaan-perusahaan kecil karena perusahaan besar dipandang lebih kritis oleh pihak luar.

$$
\text { Size }=\text { Ln value of assets }
$$

Leverage, merupakan ukuran rasio keuangan dan posisi kemampuan keuangan perusahaan untuk melunasi utang jangka panjangnya. Leverage diukur dengan menggunakan Long Term Debt to Total Assets. Long Term Debt to Total Assets digunakan untuk mengukur seberapa besar total aset perusahaan yang dibiayai oleh long term debt (Rusmin, 2010). Perusahaan yang memiliki rasio leverage tinggi akibat besarnya jumlah utang dibandingkan dengan total assets, yang dimiliki perusahaan, diduga melakukan manajemen laba karena perusahaan terancam default, yaitu tidak dapat memenuhi kewajiban pembayaran utang pada waktunya (Jiambalvo, 1996) 


$$
\text { Leverage }=\frac{\text { Long term debt }}{\text { Total Assets }}
$$

Growth, diukur dengan menggunakan perbandingan antara market value of equity dan book value of assets. Pertumbuhan perusahaan yang pesat membuat posisi perusahaan dimata pihak eksternal menjadi lebih baik, sehingga perusahaan akan tumbuh dan berkembang menjadi perusahaan yang besar. Pertumbuhan perusahaan ditunjukkan dengan kesempatan bertumbuh (growth opportunities) pada setiap tahap siklus hidup perusahaan.

$$
\text { Growth }=\frac{\text { Market value of equity }}{\text { Book value of assets }}
$$

Operating Cash Flow (OCF), merupakan arus kas yang diperoleh maupun dikeluarkan dari aktivitas perusahaan. OCF diukur berdasarkan OCF yang ada pada laporan arus kas akhir tahun berjalan dibagi dengan total aset tahun berjalan. Selain melihat dari aktivitas akrual, pada umumnya manajemen juga melakukan manajemen laba pada aktivitas riil, sehingga variabel Operating Cash Flow (OCF) digunakan untuk mengontrol ketergantungan OCF terhadap discretionary accruals (Rusmin Rusmin, 2010)

$$
\text { Operating Cash Flow }=\frac{\text { Operating Cash Flow }}{\text { Total Assets }}
$$

\section{HASIL DAN DISKUSI}

Tabel 1 menyajikan statistik deskriptif untuk variabel penelitian. Dari tabel 1 dapat dilihat bahwa masih terdapat perusahaan yang melakukan praktek manajemen laba baik dengan cara menurunkan atau menaikkan laba mereka. Sementara itu, nilai terendah dan tertinggi penghitungan Discretionary Accruals (DA) adalah penghitungan dengan cara menggunakan Modified Jones. Praktek manajemen laba negatif tertinggi paling banyak dilakukan oleh Rimo International Lestari yang mendapatkan nilai terendah selama 5 tahun. Sementara untuk manajemen laba positif paling banyak dilakukan oleh Tiphone Mobile Indonesia selama 2 tahun.

Untuk kesulitan keuangan yang dikategorikan dalam Distress 1, Distress2 dan Distress3, rata-rata perusahaan lebih banyak mengalami kondisi Distress2 (Working Capital Negatif) dibandingkan yang lainnya. Hal ini berarti kondisi kesulitan keuangan yang terjadi banyak diakibatkan karena jumlah utang lancar yang terlalu besar dibandingkan aset lancar sehingga dikhawatirkan perusahaan tersebut tidak mampu melunasinya. Di sisi lain, hanya sedikit perusahaan yang mengalami kesulitan keuangan kategori Distress 3 (Net Income dan Working Capital negatif).

Untuk variabel ukuran perusahaan (size), nilai terkecil dimiliki oleh Rimo International Lestari, sementara untuk ukuran perusahaan yang terbesar adalah Astra International. Untuk variabel Growth perusahaan yang memiliki pertumbuhan paling tinggi adalah Centratama Telekomunikasi Indonesia, sementara untuk variabel Leverage, perusahaan dengan nilai tertinggi adalah Graha Layar Prima dan untuk variabel OCF nilai tertinggi adalah Mitra International Resources.

Tabel 1

Statistik Deskriptif Seluruh Variabel

\begin{tabular}{lccccc}
\hline & $\mathrm{N}$ & Min & Max & Mean & Stdev \\
\hline Mjones & 2345 & -0.48454 & 0.466268 & -0.00804 & 0.131236 \\
Kothari & 2345 & -0.41126 & 0.398625 & -0.00574 & 0.113992 \\
Kaznik & 2345 & -0.39096 & 0.388979 & -0.00025 & 0.103456 \\
Distress1 & 2345 & 0 & 1 & 0.181663 & 0.385649 \\
Distress2 & 2345 & 0 & 1 & 0.205544 & 0.404185 \\
Distress3 & 2345 & 0 & 1 & 0.053731 & 0.225535 \\
Size & 2345 & 5081.02 & 260000000 & 7165707 & 17604277 \\
Growth & 2345 & 0.0000 & 2.41779 & 1.151504 & 0.300812 \\
Leverage & 2345 & 0.0000 & 0.716674 & 0.131467 & 0.156545 \\
OCF & 2345 & -0.31362 & 0.445143 & 0.065807 & 0.10504 \\
\hline
\end{tabular}


Tabel 2

Statistik Deskriptif Variabel Financial Distress

\begin{tabular}{|c|c|c|c|c|c|}
\hline & $\begin{array}{l}\text { Frekuensi } \\
\text { Dummy=1 }\end{array}$ & $\begin{array}{l}\text { Persentase } \\
\text { Dummy=1 }\end{array}$ & $\begin{array}{l}\text { Frekuensi } \\
\text { Dummy }=0\end{array}$ & $\begin{array}{l}\text { Persentase } \\
\text { Dummy }=0\end{array}$ & Total \\
\hline Distress 1 & 426 & $22.20 \%$ & 1919 & $77.80 \%$ & 2345 \\
\hline Distress2 & 482 & $25.87 \%$ & 1863 & $74.13 \%$ & 2345 \\
\hline Distress 3 & 126 & $5.68 \%$ & 2219 & $94.32 \%$ & 2345 \\
\hline \multicolumn{6}{|c|}{$\begin{array}{l}\text { Distress } 1=\text { Net Income Negatif } \\
\text { Distress2 }=\text { Working Capital Negatif } \\
\text { Distress } 3=\text { Net Income dan Working Capital Negatif } \\
\text { Dummy } 1=\text { Apabila perusahaan mengalami kondisi tersebut } \\
\text { Dummy } 0=\text { Apabila perusahaan tidak mengalami kondisi tersebut }\end{array}$} \\
\hline
\end{tabular}

Tabel 2 menyajikan statistic deskriptif untuk variable financial distress. Dari tabel 2 dapat dilihat bahwa kondisi Distress 2 lebih banyak dialami oleh perusahaan di Indonesia dibandingkan kategori lainnya. Hal ini dapat dilihat bahwa dari 2345 sampel, perusahaan yang pernah mengalami distress2 sebanyak 482 perusahaan atau sebesar $25.87 \%$. Selain permasalahan Working Capital, perusahaan juga mengalami kesulitan keuangan yang diakibatkan oleh Net Income Negatif sebanyak 426 perusahaan atau $22.2 \%$. Kondisi kesulitan keuangan yang jarang terjadi adalah Distress 3 dimana perusahaan mengalami Net Income dan Working Capital negatif secara bersamaan yaitu sebanyak 126 atau $5.68 \%$.

Tabel 3

Hasil Regresi

\begin{tabular}{lccccccccc}
\hline & \multicolumn{3}{c}{ Model 1 } & \multicolumn{3}{c}{ Model2 } & \multicolumn{3}{c}{ Model3 } \\
& Coef. & Std. Err & $\mathrm{P}>|\mathrm{t}|$ & Coef. & Std. Err & $\mathrm{P}>|\mathrm{t}|$ & Coef. & Std. Err & $\mathrm{P}>|\mathrm{t}|$ \\
\hline Cons & 0.3081 & 0.112 & 0.006 & 0.1321 & 0.0661 & 0.046 & 0.2395 & 0.0979 & 0.015 \\
Distress1 & -0.0857 & 0.0099 & 0.000 & -0.0883 & 0.0073 & 0.000 & -0.0664 & 0.008 & 0.000 \\
Distress2 & -0.006 & 0.0105 & 0.568 & 0.0011 & 0.0083 & 0.892 & 0.0035 & 0.0098 & 0.721 \\
Distress3 & -0.01 & 0.0186 & 0.59 & -0.0214 & 0.0132 & 0.105 & -0.0202 & 0.0157 & 0.199 \\
Size & -0.0188 & 0.0077 & 0.015 & -0.0098 & 0.0046 & 0.034 & -0.0139 & 0.0066 & 0.037 \\
Growth & -0.2732 & 0.0122 & 0.26 & -0.0359 & 0.0068 & 0.52 & -0.021 & 0.0109 & 0.54 \\
OCF & -0.8499 & 0.0533 & 0.52 & -0.1988 & 0.0246 & 0.287 & -0.8307 & 0.0478 & 0.471 \\
Leverage & 0.1146 & 0.0359 & 0.007 & 0.1701 & 0.0214 & 0.040 & 0.1057 & 0.3271 & 0.007 \\
\hline R-sq Within & & 0.3389 & & & 0.1309 & & & 0.4067 & \\
Prob $>$ F & & 0.0000 & & & 0.0000 & & & 0.0000 & \\
\hline
\end{tabular}

Tabel 3 menyajikan hasil uji hipotesis. Pada masing-masing model dapat dilihat mendapatkan nilai koefisien konstanta yang positif. Hal ini berarti apabila variabel independen dan variabel kontrol adalah nol maka terdapat manajemen laba yang positif yang berarti perusahaan akan melakukan manajemen laba dengan cara menaikkan laba. Pada tabel 4.9 terlihat hasil yang menunjukkan negatif pada semua model, namun untuk variabel distress 2 didapatkan hasil yang berbeda dimana pada model 1 didapatkan hasil yang negatif sementara pada model 2 dan model 3 didapatkan hasil yang positif. Sementara itu untuk uji t-test, variabel distress 1 memiliki nilai signifikan sebesar 0.000 pada semua model yang berarti variabel tersebut memiliki hubungan negatif dan signifikan terhadap DA. Namun untuk variabel distress 2 dan distress 3 pada setiap model didapatkan hasil yang tidak signifikan. 
Untuk variabel kontrol size didapatkan hasil yang sama pada setiap model yaitu negatif dan signifikan. Sementara pada variabel growth didapatkan hasil positif pada semua model namun hanya model 1 dan model 2 yang hasil uji t-test di bawah 5 persen yang berarti hanya model 1 dan model 3 yang signifikan, sementara model2 tidak signifikan. Variabel OCF memiliki hasil negatif dan signifikan pada semua model dan variabel leverage memiliki hasil negatif namun tidak signifikan pada semua model.

Sementara itu, untuk melihat signifikan pengaruh variabel independen secara bersama-sama atas suatu variabel dapat dilihat dari hasil Uji F. Berdasarkan tabel 4.9 dapat dilihat bahwa setiap model memiliki probabilitas sebesar 0.0000 yang nilainya di bawah 0.05 . Hal ini berarti semua variabel independen berpengaruh signifikan secara simultan (bersama-sama) terhadap manajemen laba.

Selain itu, untuk hasil pengujian Koefisien determinasi (R2) yang digunakan untuk mengukur seberapa jauh kemampuan model dalam menerangkan variasi variabel dependen. Dari tabel 4.9 dapat dilihat bahwa pada model 1 didapatkan koefisien determinasi sebesar $0.3389,0.4067$ pada model 2 dan 0.1309 pada model 3. Hal ini berarti pada model 1 kemampuan variabel independen dalam menerangkan variasinya terhadap perubahan manajemen laba adalah sebesar $33.89 \%$ yang berarti masih terdapat faktor-faktor lain di luar model regresi yang dianalisis.

\section{Pengaruh Distress1 terhadap Manajemen laba}

Hasil penelitian menggunakan uji t-test yang dapat dilihat pada tabel 4.12 menunjukkan bahwa variabel Distress 1 yang ditandai dengan net income negatif selama tahun berjalan memiliki hubungan negatif dan signifikan terhadap seluruh model Discretionary Accruals (DA) dengan nilai signifikan sebesar 0.0000 yang menunjukkan bahwa perusahaan yang mengalami kesulitan keuangan maka DA semakin turun. Hal ini mengindikasikan bahwa manajemen pada perusahaan yang mengalami kondisi net income negatif cenderung melakukan manajemen laba untuk menurunkan laba (income decreasing) dengan cara mengakui semua beban-beban pada saat ini sehingga di tahun depan seolaholah terdapat peningkatan laba (perbaikan kondisi) dari perusahaan tersebut, sehingga para investor akan melihat kalau perusahaan tersebut telah pulih dari kesulitan keuangan. Hal ini sesuai dengan penelitian terdahulu oleh Gunawan (2014) dan Habib et al. (2012) yang menggunakan metode pengukuran yang sama menemukan bahwa semakin perusahaan mengalami kondisi kesulitan keuangan maka perusahaan semakin banyak melakukan praktek manajemen laba.

\section{Pengaruh Distress2 terhadap Manajemen laba}

Untuk variabel distress 2 yang pengukurannya adalah ketika kondisi keuangan perusahaan dengan working capital negatif selama tahun berjalan menghasilkan hubungan negatif dan tidak signifikan pada model 1 , namun pada model2 dan model3 didapatkan hasil positif dan tidak signifikan. Hal ini berarti bahwa ketika working capital perusahaan negatif tidak maka tidak akan berpengaruh bagi manajemen untuk melakukan manajemen laba dikarenakan para investor lebih banyak memperhatikan laba perusahaan dibandingkan modal kerja perusahaan. Hal ini didukung oleh penelitian yang dilakukan Riduwan (2001) yang mengatakan bahwa pada prakteknya yang banyak menjadi perhatian investor dan calon investor dalam laporan keuangan hanya terpusat pada laba (earnings) perusahaan karena pada dasarnya laba yang dilaporkan oleh manajemen merupakan sinyal bagi para pengguna laporan keuangan terutama mengenai laba perusahaan di masa mendatang.

\section{Pengaruh Distress3 terhadap Manajemen laba}

Variabel distress 3 yang diukur dengan melihat kondisi keuangan perusahaan yang mengalami net income maupun working capital yang negatif selama tahun berjalan didapatkan hasil hubungan negatif dan tidak singnifikan. Hal ini menunjukkan bahwa net income maupun working capital tidak berpengaruh terhadap manajemen untuk melakukan manajemen laba karena selain net income dan working capital masih terdapat banyak faktor lain yang diperhatikan investor sebelum berinvestasi seperti GCG (Hapsoro dan Hartomo,2016). Dengan adanya GCG, investor akan lebih percaya bahwa laporan keuangan yang disajikan sesuai dengan kondisi yang sebenarnya, sehingga hal ini akan mendorong investor untuk berinvestasi pada perusahaan yang memiliki GCG. Hasil pengujian ini bertentangan dengan penelitian Gunawan (2014) yang menemukan bahwa variabel DISTRESS3 berpengaruh positif dan signifikan terhadap manajemen laba. 
Dapat disimpulkan bahwa kesulitan keuangan baik itu kesulitan keuangan yang terjadi ketika net income negatif, modal kerja negatif atau ketika net income dan modal kerja negatif didapatkan pengaruh negatif terhadap manajemen laba. Hal ini didukung oleh signaling theory (Jensen,1976) yang mengatakan bahwa ketika kondisi keuangan dan prospek perusahaan buruk, maka manajemen akan memberikan sinyal dengan mencatat akrual diskresioner negatif atau melakukan manajemen laba dengan cara menurunkan laba usaha untuk menunjukkan bahwa kondisi keuangan perusahaan dan laba periode kini serta yang akan datang lebih buruk dari pada laba non-diskresioner periode kini. Hal ini dikarenakan dalam kondisi keuangan buruk, manajer akan memberikan sinyal kabar buruk dengan tujuan memberikan informasi kepada pasar bahwa mereka mempunyai integritas, bertindak jujur, dan mempunyai keyakinan dapat mengatasi masalah yang dihadapi. Selain untuk menunjukkan kualitas manajerial mereka, dengan memberikan sinyal buruk, manajemen mungkin berharap memperoleh apresiasi dari pasar untuk menahan penurunan harga saham perusahaan.

Kondisi ini juga didukung oleh teori manajemen laba (Scott, 1997) yang menyatakan bahwa terdapat dua perspektif manajer melakukan manajemen laba yaitu opportunistic dan efficient. Pada kondisi kesulitan keuangan, manajer akan cenderung bersifat efficient dikarenakan tindakan manajemen laba tersebut memang harus dilakukan dikarenakan masalah kesulitan keuangan secara tidak langsung berhubungan dengan keberlangsungan perusahaan yang apabila tidak diselesaikan secara cepat dan benar dapat menyebabkan perusahaan mengalami kebangkrutan.

\section{SIMPULAN, IMPLIKASI, DAN KETERBATASAN}

Tujuan dari penelitian ini adalah mengetahui bagaimana hubungan antara kesulitan keuangan dengan manajemen laba yang diukur menggunakan nilai Discretionary Accruals (DA). Hasil dari penelitian ini menunjukkan (1) terdapat hubungan negatif signifikan antara kesulitan keuangan kategori distress 1 yang ditandai dengan net income negatif selama tahun berjalan dengan manajemen laba, (2) tidak ada hubungan signifikan antara kesulitan keuangan pada kategori distress 2 yang ditandai dengan working capital negatif selama tahun berjalan dengan manajemen laba, (3) tidak terdapat hubungan antara kesulitan keuangan pada kategori distress 3 yang ditandai dengan net income dan working capital negatif selama tahun berjalan dengan manajemen laba.

Penelitian ini tentunya memberikan implikasi salah satunya bagi investor, disarankan untuk lebih meninjau kondisi keuangan terkait kemampuan perusahaan dalam mengelola aset lancar untuk membiayai utangnya dan memperoleh laba yang maksimal agar dapat memprediksi praktek manajemen laba, karena perusahaan yang mengalami kesulitan keuangan cenderung melakukan manajemen laba agar dapat menarik perhatian dan mempertahankan performa kinerja di mata investor.

Periode penelitian yang digunakan dalam penelitian ini hanya 7 tahun yaitu dari tahun 2010-2016 namun tidak memperhatikan kondisi ekonomi yang sedang terjadi di Indonesia baik itu sedang krisis ataupun tidak yang secara tidak langsung dapat berdampak pada tingkat kesulitan keuangan perusahaan. Penelitian selanjutnya sebaiknya membandingkan analisis ketika kondisi ekonomi yang terjadi misalnya apabila negara tersebut sedang mengalami krisis atau tidak. Karena kondisi krisis ekonomi dapat meningkatkan risiko perusahaan untuk mengalami kesulitan keuangan sehingga akan menimbulkan praktek manajemen laba.

\section{DAFTAR PUSTAKA}

Ahmed \& Al-khabash, 2008. Earnings Management Practices from the Perspective of external and internal auditors: Evidence from Jordan. Managerial Auditing Journal, Vol.24 Issue:1, pp. 58-80.

Albrecht, W. \& Richardson, F., 1990. Income Smoothing by Economy Sector. Journal of Business Finance \& Accounting Vol.17 (5), pp. 713-730.

Assih, P. \& Gudono, M., 2000. Hubungan Tindakan Perataan Laba dengan Reaksi Pasar atas Pengumuman Informasi Laba Perusahaan yang terdaftar di Bursa Efek Jakarta. Simposium Nasional AKuntansi II. 
Brigham, E. \& Houston, 2006. Fundamental of Financial Management : Dasar-Dasar Manajemen Keuangan Edisi 20. Jakarta: Salemba Empat.

Dechow, P. S. R. S. A., 1995. Detecting Earnings Management. The Accounting Review 70, No 2, pp. 193-225.

DeVega, W. \& Amanah, L., 2014. Hubungan Antara Financial Distress Terhadap Earnings Management. Journal ilmu \& Riset Akuntansi Vol.03 No.4.

Elmabrok, M. A. A., 7 July 2012. Using Altman Model and Current Ratio to Assess the Financial Status of Companies Quote of Malaysian Stock Exchange. International Journal of Scientific and Research Publications Volume 2, pp. 1-11.

Fischer, M. \& Rosenzweig, K., 1995. Attitude of Students and Accounting Practitioners Concerning the Ethical Acceptability of Earnings Management. Journal of Business Ethics. Vol. 14, pp. 433444.

Ghozali, I., 2011. Aplikasi Analisis Multivariate Dengan Program SPSS. Semarang: Badan Penerbit Universitas Diponegoro.

Gitosudarmo, I., 2002. Manajemen Keuangan. Yogyakarta: BPFE.

Gunawan, F. F., Rudiawarni, F. A. \& Sutanto, A. C., 2014. Hubungan Antara Financial Distress Dengan Earnings Management pada Badan Usaha Sektor Manufaktur yang Terdaftar di BEI Periode 2010-2012. Jurnal Ilmiah Mahasiswa Universitas Surabaya Vol.3 No.1, pp. 1-18.

Habib, A., Bhuiyan, M. B. u. \& Islam, A., 2013. Financial distress, earnings management and market pricing of accruals during the global financial crisis. Managerial Finance, 39(2), pp. 155-180.

Jensen M.C., M. W., 1976. Theory of the firm: Managerial behavior, agency costs and ownership structure. Journal of Financial Economics, pp. 305-360.

Kasznik, R., 1999. On the Association between Voluntary Disclosure and Earnings Management. Journal of Accounting Research, 37(1), pp. 57-81.

Koch, A. S., 2002. Financial Distress and The Credibility of Management Earnings Forecast. The Lahore Journal of Economics Vol. 18 No. 1, pp. 81-92.

Kothari, S., Leone, A. J. \& Wasley, C. E., 2005. Performance matched discretionary accrual measures. Journal of Accounting and Economics, 39(1), pp. 163-197.

Lo, E. W., 2012. Pengaruh Tingkat Kesulitan Keuangan Terhadap Manajemen Laba: Teori Keagenan Versus Teori Signaling. Journal Akuntansi Vol 9. No 1, pp. 1-18.

Martono \& Harjito, A., 2010. Manejemen Keuangan (Edisi 3). Yogyakarta: Ekonisia.

McKeown, J., Mutchler, J. \& W.Hopwood, 1991. Towards an Explanation of auditor failure to modify audit reports of bankrupt companies. A Journal of Practice \& Theory 10, pp. 1-13.

Platt HO, P. H., 2002. Predictiong Corporate FInancial Distress: Reflections On ChiceBased Sampel Bras. Journal of Economic and Finance Vol 26 No 2, pp. 184-203.

Riyanto, B., 2001. Dasar-Dasar Pembelanjaan Perusahaan. Yogyakarta: BPFE. 
Rusmin, 2010. Audit QUality and Earnings Management: Singapore Evidence. Managerial Auditing Journal, VOl. 25, No. 7, pp. 618-638.

Scott, W. R., 2015. Financial Accounting Theory (7th Edition). s.1.:Pearson.

Sugiyono, 2010. Metode Penelitian Pendidikan Pendekatan Kuantitatif, Kualitatif, dan R\&D. Bandung: Alfabeta.

Supardi, 2003. Validitas Penggunaan Z-SCore Altman Untuk Menilai Kebangkrutan Pada Perusahaan Perbankan Go-Public di Bursa Efek Jakarta. KOMPAK No.7. 